\title{
Asymptomatic Leishmania chagasi Infection in Relatives and Neighbors of Patients with Visceral Leishmaniasis
}

\section{Argemiro D’Oliveira Júnior, Sérgio Ricardo M Costa, Aurinha Bispo Barbosa*, Maria de La Glória Orge Orge, Edgar M Carvalho/ ${ }^{+}$}

\author{
Laboratório de Imunologia, Hospital Universitário Prof. Edgar Santos, Rua João das Botas s/nº, 40110-160 \\ Salvador, BA, Brasil *Posto de Saúde de Monte Gordo, Camaçari, BA, Brasil
}

\begin{abstract}
The frequency of asymptomatic infection among relatives and neighbors of cases of visceral leishmaniasis (VL) was compared and characterization of the immunological response in these subjects was performed. Cases were from a new endemic area, close to the beach and near Salvador, capital of the State of Bahia, Brazil. The characterization of asymptomatic infection was made using a skin reaction test and detection of antibody to Leishmania chagasi by the ELISA test. To characterize the immunological response of these subjects with asymptomatic L. chagasi infection the cytokines profile and the lymphoproliferative response were determined after stimulation of lymphocytes by $\mathrm{L}$. chagasi antigen. There was no difference in the frequency of $\mathrm{L}$. chagasi infection in relatives (45\%) and in neighbors $(27 \%)$ of cases of $V L(P>0.05)$. The immunological response from these subjects was characterized by high production of IFN-gand a low production of IL-10 and a good lymphoproliferative response to L. chagasi antigen.
\end{abstract}

Key words: visceral leishmaniasis - asymptomatic infection - relatives' infections

There is evidence that in endemic areas of visceral leishmaniasis (VL) only about $20 \%$ of the subjects infected by Leishmania chagasi will develop classical VL. The majority of the infected individuals have a sub-clinical infection that may remain completely asymptomatic or have an oligosymptomatic form of the disease. Subjects with oligosymptomatic infection may develop clinical VL months after the seroconvertion or may self heal their infections one or two years after the seroconvertion (Badaró et al. 1986a). In Brazil the majority of patients who develop VL are malnourished children with mean age of 3 years (Badaró at al. 1986b). Depression of cellular immune response is also involved in the development of the disease since infected subjects whose lymphocytes do not proliferate and do not produce IFN-g upon leishmania stimulus are in the group who will progress from the infection to disease (Carvalho et al. 1992). The evidence of VL cluster in families could be an indication that genetic factors may predispose the development of the disease (Evans et al. 1992). Alternatively a great number of cases of VL in one family may be related to increased exposure since L. chagasi transmission is predominantly

${ }^{+}$Corresponding author. Fax: +55-71-245.7110

Received 29 April 1996

Accepted 21 August 1996 peridomiciliar. It was demonstrated an intrafamilial pattern of infection in VL in an endemic area (Jacobina, BA, Brazil) with a strong suggestion of at least partial genetic involvement (Cabello et al. 1995).

The majority of the cases of VL in Brazil occur in communities localized in the interior of the Northeastern region of the country. In 1989, an outbreak of VL was reported in villages of the municipality of Camaçari, approximately $2 \mathrm{~km}$ from the beach and $50 \mathrm{~km}$ north of Salvador, the capital of the State of Bahia. An epidemiological and clinical study in one of the villages has documented authoctoneous cases of disease and infected dogs (Cunha et al. 1995). In the present study we have determined by serological test and intradermal reaction the frequency of $L$. chagasi infection in relatives and neighbors of patients with VL who lived in these areas. In addition we characterized the cytokines profile secreted by lymphocytes from subjects with asymptomatic $L$. chagasi infection upon stimulation with leishmania antigen.

\section{MATERIALS AND METHODS}

The study was conducted in the villages of Monte Gordo and Barra do Jacuípe that are located at sea level along the Coco road, which links Salvador with coastal towns of the State of Bahia. These villages have a population nearly 6000 inhabitants and 10 to 12 cases of VL have been reported annually since 1989 . There are no cases of 
cutaneous or mucosal leishmaniasis in this area. Participants of the present study included relatives and neighbors of 12 patients who had VL diagnosed between June of 1992 and May of 1993. The patients with VL were diagnosed by finding amastigotes of $L$. chagasi in material obtained from bone marrow or spleen aspiration stained by $\mathrm{Gi}$ emsa. In order to determine the frequency of infection in relatives and neighbors we evaluated the father, mother, siblings, brother and sister living in the same house of the cases and the neighbors who lived no more than $100 \mathrm{~m}$ of the cases of VL. This distance of no more than $100 \mathrm{~m}$ was chosen based on evidence of the mean flight range of phlebotomines (Southgate \& Oriedo 1967). The patients, parents and neighbors share the same socio-cultural, economic and environmental conditions. The subjects evaluated in this study, $100 \%$ of the relatives and $95 \%$ of the neighbors of the cases of VL had a clinical history and examination, a serological test to detect antibodies against L. chagasi and an intradermal skin test with leishmania antigen. Additionally we characterized the cytokine profile in 11 subjects with asymptomatic infection and compared these findings with those observed in 5 subjects cured of VL and 5 with active VL.

Leishmania antigen, antibody detection and skin test - Leishmania lysate was obtained from promastigotes of a strain isolated from a patient with VL and characterized by monoclonal antibodies and isoenzymes as L. chagasi (MHOM Ba 62). Briefly, promastigotes in the stationary phase of growth from cultures were washed three times in PBS, re-suspended and rapidly frozen $\left(-70^{\circ} \mathrm{C}\right)$ and thawed $\left(37^{\circ} \mathrm{C}\right)$ six times (Reed et al. 1986). After sonication the lysate was centrifuged $(12000 \mathrm{xg})$ for $20 \mathrm{~min}$, the supernatant was collected, and protein content was determined by using the method of Lowry et al. (1951).

An ELISA to detect antibodies against leishmania using 1:100 dilution of assayed sera was done as previously described (Badaró et al. 1986c). A serological test was considered positive when the OD was $>0.040$ which represents the mean plus 3 SD of absorbancies obtained of sera from individuals without exposure to leishmania.

Lymphocyte blastogenesis test and cytokine determination - Peripheral blood mononuclear cells were obtained from heparinized venous blood by centrifugation using lymphocyte separation medium (Bionetics Laboratory Products Kensington, MD) as previously described (Carvalho \& Horwitz 1980). After washing in RPMI 1640 (GIBCO, Grand Island, NY) and adjusted to a concentration of $10^{6}$ cells $/ \mathrm{ml}$ in medium supplemented with $10 \%$ pooled human $A B$ serum, triplicate samples (aliquots $0.2 \mathrm{ml}$ ) of this cell suspension were cultured in microtiter plates (Limbro Chemical, New Heaven, CT). Cell cultures were incubated $\left(37^{\circ} \mathrm{C}\right.$, $5 \% \mathrm{CO}_{2}$ ) for 5 days with $L$. chagasi antigen $(1 \mathrm{mg} /$ $\mathrm{ml}$ of protein). The cells were then pulsed with $1 \mathrm{mCi}$ ${ }^{3}[\mathrm{H}]$-thymidine for the final $6 \mathrm{hr}$ of culture. The results are expressed as the mean response of ${ }^{3}[\mathrm{H}]$ thymidine incorporation in triplicate cultures.

For IFN-gand IL-10 detection, the PBMC were adjusted to $3 \times 10^{6}$ cells $/ \mathrm{ml}$ and stimulated with $20 \mathrm{mg}$ of $L$. chagasi antigen. After $48 \mathrm{hr}$ the cells were centrifuged and the supernatant filtered and stored at $-20^{\circ} \mathrm{C}$ until use. Gamma-interferon and IL-10 levels were determined by ELISA using a sandwich technique (Russo et al. 1993). A standard curve was used to express the results in $\mathrm{pg} / \mathrm{ml}$.

Statistical analysis - Data on frequency of positive ELISA and/or positive intradermal skin test in relative and neighbors was performed by $\mathrm{c}^{2}$ test with correction of Yates. Data on lymphocyte proliferation and cytokine production were compared by rank sum test. To calculate the risk of infection for $L$. chagasi we used the odds ratio (OR) with 95\% confidence intervals. Levels of statistical significance were designated at $\mathrm{P}<0.05$ (two-tailedtest).

\section{RESULTS}

The clinical and demographic findings of 12 cases of VL are shown in Table I. The age of the patients ranged from 2 to 46 years with median of 26 years. In five cases the age was equal or lower than 10 years. Seven patients lived in the villages since they were born. The others were living in the villages for at least the last six years. The duration of the illness in such cases ranged from 15 to 90 days. There was a cluster of cases of VL in families since 8 of the 12 patients belonged to three families. Two families with two cases and one family with four cases. ELISA test to detect $L$. chagasi antibodies and intradermal skin with leishmania antigen test were performed in relatives and neighbors $(n=135)$ of the VL cases. All subjects tested had no present complain related to VL and they denied previous diagnosis of VL. Evidence of $L$. chagasi infection determined by a positive ELISA or intradermal skin test (Table II) was documented in 18 of 40 relatives (45\%) and in 26 of 95 (27\%) of the neighbors of the VL cases $(\mathrm{P}>0.07$; $\mathrm{OR}=2.17: 1.0$ - 4.7). The age distribution of subjects infected by $L$. chagasi followed the age distribution of the sample (data not shown). In all age groups there was a higher number of cases with positive skin test than that subjects with positive serology (data not shown). L. chagasi infection, determined by positive serological test and or positive skin test, was observed in $31(39.7 \%)$ of the 
TABLE I

Clinical features of visceral leishmaniasis in a recent area of Leishmania chagasi transmission

\begin{tabular}{lcccccc}
\hline $\begin{array}{l}\text { Patients } \\
\text { initials }\end{array}$ & Age/Sex & $\begin{array}{c}\text { No. of years } \\
\text { living in the area }\end{array}$ & Hepatomegaly & Splenomegaly & $\begin{array}{c}\text { ELISA } \\
(\text { OD })\end{array}$ & $\begin{array}{c}\text { Parasite } \\
\text { isolation }\end{array}$ \\
\hline JPC & $2 / F$ & 2 & Yes & Yes & 0,194 & Yes \\
DSB & $4 / F$ & 4 & Yes & Yes & 0,50 & Yes \\
RCS & $5 / F$ & 5 & Yes & Yes & 0,208 & Yes \\
LSC & $6 / F$ & 6 & Yes & Yes & 0,67 & Yes \\
LSC & $10 / F$ & 6 & Yes & Yes & 0,46 & Yes \\
ANS & $19 / \mathrm{M}$ & 19 & Yes & Yes & 0,154 & Yes \\
IBS & $32 / \mathrm{F}$ & 30 & Yes & Yes & 0,164 & Yes \\
JLF & $39 / \mathrm{M}$ & 8 & No & No & 0,180 & No \\
MDS & $39 / \mathrm{M}$ & 39 & Yes & Yes & 0,137 & Yes \\
RDS & 41/M & 41 & No & Yes & 0,49 & Yes \\
ACS & $55 / M$ & 6 & No & No & 0,256 & Yes \\
LES & $58 / F$ & 10 & Yes & Yes & 0,96 & Yes \\
\hline
\end{tabular}

TABLE II

Frequency of relatives and neighbors of visceral leishmaniasis cases with evidence of antibodies or positive skin test to Leishmania chagasi

\begin{tabular}{lccc}
\hline & \multicolumn{3}{c}{ Evidence of infectivity } \\
\cline { 2 - 4 } Population & Positive (\%) & Negative (\%) & Total \\
\hline Relatives $^{b}$ & $18(45)$ & $22(55)$ & 40 \\
Neighbors & $26(27)$ & $69(73)$ & 95 \\
\hline Total & 44 & 91 & 135 \\
\hline
\end{tabular}

$a$ : serology and/or intradermal skin test positive; $b$ : parents, children and brothers.

78 subjects older than 13 years and in $13(22.8 \%)$ of 57 children aged 13 years or less $(\mathrm{P}=0.04$; $\mathrm{OR}=2.23: 1.03-4.8$ ). None of the population had splenomegaly and none developed VL after one year and half of follow-up.
To characterize the $\mathrm{T}$ cell response in these subjects with asymptomatic $L$. chagasi infection the lymphocyte proliferative response and the cytokine profile produced after in vitro stimulation with L. chagasi were evaluated (Table III). Eleven subjects, mean age of $28 \pm 20$, participated of the immunological study being five with negative ELISA test and positive intradermal skin test, five with positive ELISA and negative intradermal reaction and one case with both tests positive. As control $\mathrm{T}$ cell response was performed in five subjects cured of VL (mean age 29 \pm 11 ) and five VL patients (mean age $16 \pm 6$ ).

The ${ }^{3}[\mathrm{H}]$-thymidine uptake of lymphocyte cultures ranged from 2205 to $54373 \mathrm{cpm}$ with mean and SD of $30966 \pm 15111$. The IFN-g production ranged from $<20$ to $1234 \mathrm{pg} / \mathrm{ml}$ with mean of $601 \pm 391 \mathrm{pg} / \mathrm{ml}$. The magnitude of lymphocyte

TABLE III

Lymphoproliferative response and cytokine profile of subjects with asymptomatic Leishmania chagasi infection

\begin{tabular}{|c|c|c|c|c|c|c|}
\hline \multirow[b]{2}{*}{ Age/Sex } & \multirow[b]{2}{*}{ ELISA } & \multirow[b]{2}{*}{ Skin test } & \multicolumn{2}{|c|}{ 3H-Thymidine } & \multicolumn{2}{|c|}{ Cytokine levels $(\mathrm{pg} / \mathrm{ml})$} \\
\hline & & & Media & L. chagasi & IFN-g & IL-10 \\
\hline $7 / \mathrm{F}$ & - & + & $864 \pm 315$ & $41380 \pm 1265$ & 670 & 25 \\
\hline $11 / \mathrm{F}$ & - & + & $1119 \pm 332$ & $45735 \pm 939$ & 410 & 48 \\
\hline $13 / \mathrm{F}$ & - & + & $2596 \pm 126$ & $54373 \pm 4800$ & 851 & 26 \\
\hline $16 / \mathrm{M}$ & - & + & $297 \pm 85$ & $21631 \pm 1842$ & 1234 & 47 \\
\hline $19 / \mathrm{M}$ & - & + & $567 \pm 115$ & $44382 \pm 2765$ & 785 & 18 \\
\hline $19 / \mathrm{M}$ & + & - & $861 \pm 110$ & $22141 \pm 1353$ & 300 & 19 \\
\hline $24 / \mathrm{F}$ & + & - & $367 \pm 111$ & $15857 \pm 1589$ & 1220 & 25 \\
\hline $35 / \mathrm{F}$ & + & - & $940 \pm 103$ & $32921 \pm 9633$ & 237 & 19 \\
\hline $43 / \mathrm{M}$ & + & - & $478 \pm 130$ & $31370 \pm 3280$ & 480 & 24 \\
\hline $55 / \mathrm{M}$ & + & - & $684 \pm 75$ & $2205 \pm 638$ & $<20$ & 26 \\
\hline $72 / \mathrm{F}$ & + & + & $731 \pm 182$ & $28654 \pm 1285$ & 410 & 21 \\
\hline \multirow{2}{*}{\multicolumn{3}{|c|}{$\begin{array}{l}\text { Active visceral leishmaniasis }(n=5) \\
\text { Cured visceral leishmaniasis }(n=5)\end{array}$}} & $743 \pm 587$ & $926 \pm 334$ & $15 \pm 8$ & $387 \pm 118$ \\
\hline & & & $862 \pm 316$ & $37286 \pm 12345$ & $547 \pm 263$ & $27 \pm 11$ \\
\hline
\end{tabular}


proliferation and cytokine production was not different when we compared subjects with positive skin test with those with negative skin test ( $p>0.05)$. Of the eleven subjects evaluated with asymptomatic infection six were neighbors and five were relatives from patients with VL. The lymphoproliferative response and cytokine production in the neighbors was not different when compared with the relatives of the VL cases $(\mathrm{P}>0.05)$. The IFN-g production by subjects with asymptomatic $L$. chagasi infection was higher $(\mathrm{P}<0.05)$ than that observed in patients with active VL $(15 \pm 8 \mathrm{pg} / \mathrm{ml})$ and similar $(\mathrm{P}>0.05)$ to that observed in subjects cured of VL $(547 \pm 263 \mathrm{pg} / \mathrm{ml})$. In contrast with the high production of IFN-gobserved in the subjects with asymptomatic $L$. chagasi infection there was a very low production of IL-10. The IL-10 levels in subjects with asymptomatic $L$. chagasi infection $(27 \pm 11 \mathrm{pg} / \mathrm{ml})$ were lower $(\mathrm{p}<0.01)$ than those observed in patients with active VL $(387 \pm 118 \mathrm{pg} /$ $\mathrm{ml})$.

\section{DISCUSSION}

In the present study we showed that although cases of VL tend to occur in the same family, the frequency of the $L$. chagasi infection in relatives in the same house of patients with VL was similar to that observed in neighbors of this same patients. Additionally, the immunological studies in subjects with asymptomatic L. chagasi infection showed that upon leishmania antigen stimulation, these individuals produce high amount of IFN-gand very little IL-10.

Several factors have been associated with predisposition of development of VL. Among these factors are: low age, malnourishment and inability of lymphocytes to proliferate and to produce IFNgupon exposition to L. chagasi antigen (Badaró et al. 1986a, Carvalho et al. 1992). In contrast, very little information is known regarding factors involved in acquisition of $L$. chagasi infection and why the majority of the population infected by $L$. chagasi is able to control the progression of the infection to the disease.

Epidemiological studies performed in areas of L. chagasi transmission have shown that VL occurs predominantly in children (Guedes et al. 1974, Wijers \& Killu 1984, Navin et al. 1985, Jahn et al. 1986, Badaró et al. 1986b, Corredor et al. 1989, Beer et al. 1991, Evans et al. 1992). In the present study performed in a recent area of $L$. chagasi transmission we observed that the disease was more frequent in adults than in children and that the adult population was also more infected than the children $(\mathrm{P}=0.04)$. Similar findings have been observed by others in outbreaks in areas previously free of the disease (Zijlstra et al. 1991, Perea et al. 1991).
Since the majority of our patients with VL were born in the villages or have lived there for at least the last six years, a period much higher than the illness duration, and since transmission of $L$. chagasi is active (dogs have been found infected and Lutzomyia longipalpis are frequent in the area) the autochthony of all cases is highly likely. VL in adult is common in Africa where wild or domestic animals have not been identified as reservoir of $L$. donovani (WHO 1990). In the Americas transmission of L. chagasi infection is predominantly peridomiciliar (Corredor et al. 1989, WHO 1990) and the dog is the more frequent reservoir of $L$. chagasi infection (Alencar et al.1975). However several studies have failed to determine that killing of dogs decrease seroconvertion and the incidence of VL indicating that others reservoirs may be involved in L. chagasi transmission (Deane \& Deane 1962, Lainson 1983, Ward 1985, Evans et al. 1985). The findings from this study showing that VL and asymptomatic infection occur more frequently in the adult population than in children, suggests that in recent areas of $L$. chagasi transmission, a wild reservoir may have an important role. After years of transmission a high percentage of the adult population have been already infected and have control or had acquired the disease. Children then become the major target of the leishmania and malnourishment, low age and concomitant infections may now contribute to the increase incidence of the disease in childhood (Badaró et al. 1986b, Cerf et al. 1987, Evans et al. 1992).

Genetic susceptibility to leishmania infection have been reported in experimental animals (Bradley 1977, Blackwell 1982) and cases of VL have been documented in the same family. However, families not related living closely have different incidence of disease and infection (Thakur 1984, Evans et al. 1985, Costa et al. 1986, Badaró et al. 1986b, Dhiman \& Sen 1991) and evidence of a genetic predisposition for development of the human disease is lacking. In this study 8 of the 12 cases of VL that were diagnosed in a period of 12 months occurred in three families, indicating that genetic studies need to be performed. In spite of the cluster of cases of VL, there was no evidence that infection by L. chagasi determined by serodiagnosis or skin test was significantly more frequent in relatives than in neighbors of the patients with VL.

Depression of Th1 response characterized by absence of lymphoproliferative response, IL-2 and IFN-gproduction and secretion of cytokines of Th2 type such IL-4, IL-5 and IL-10 are documented in VL (Carvalho et al. 1989, Karp et al. 1993, Ghalib et al. 1993, Carvalho et al. 1994). Previously we have observed that children recently exposed to $L$. 
chagasi and able to produce IFN-gare able to control the infection or even a sub-clinical disease preventing the development of VL (Carvalho et al. 1992). This present study confirms that IFN-gproduction is a marker of individuals with asymptomatic $L$. chagasi infection. Additionally we extend the characterization of the immune responses showing that IL-10 production is low in such subjects. Marked expression of mRNA for IL-10 is observed in VL (Karp et al. 1993, Carvalho et al. 1994) and the role of this cytokine in down regulate $\mathrm{T}$ cell responses in these patients have been documented (Ghalib et al. 1993, Carvalho et al. 1994). The determination of high IFN-g and low IL-10 production in subjects with asymptomatic L. chagasi infection indicate that balance between the production of these cytokines may be an important key in determine whether subjects will or not develop disease.

IFN-g production after leishmania antigen stimulation was documented in all subjects but one and low production of IL-10 was observed in the asymptomatic subjects. These observations were similar to those observed in cured subjects and different from patients with VL that had high IL-10 and absence of IFN-gproduction. The only asymptomatic subject who did not produce IFN-gdid not produce IL-10. This subject remained asymptomatic up one year and half of seroconvertion and was only once immunologically evaluated. It is possible that if subsequent evaluations were performed, this patient became a responder as has been previously observed (Carvalho et al. 1992).

\section{ACKNOWLEDGMENTS}

To the Director of the Health Post of Monte Gordo and the other staff members specially Mr João Silva Araújo for their cooperation. To Mrs Elbe Silva and Mr Jackson Lemos for preparation of the manuscript.

\section{REFERENCES}

Alencar JE, Almeida YM, Silva ZF, Paiva AS, Fonseca MF 1975. Aspectos atuais do calazar no Ceará. Rev Bras Malariol Doença Trop 25/26: 27-48.

Badaró R, Jones TC, Carvalho EM, Sampaio D, Reed SG, Barral A, Teixeira R, Johnson WD 1986a. New perspective on a subclinical form of visceral leishmaniasis. J Infect Dis 154: 1003-1011.

Badaró R, Jones TC, Lorenço R, Cerf BJ, Sampaio D, Carvalho EM, Rocha H, Teixeira R, Johnson WD 1986b. A prospective study of visceral leishmaniasis in an endemic area of Brazil. J Infect Dis 154: 639-649.

Badaró R, Reed SG, Barral A, Orge G, Jones TC 1986c. Evaluation of the micro enzyme linked immunosorbent assay (ELISA) for antibodies in American visceral leishmaniasis antigen selection for detection of infection specific responses. Am J Trop Med Hyg 35: 79-85.
Beer P, de Harit AEC, Deng LL, Semião-Santos SJ, Chantal B, Grootheest M 1991. A killing disease epidemic among displaced sudanese population identified as visceral leishmaniasis. Am J Trop Med Hyg 44: 283-289.

Blackwell JM 1982. Genetic control of recovery from visceral leishmaniasis. Trans $R$ Soc Trop Med Hyg 76: 147-154.

Bradley DJ 1977. Regulation of the leishmania populations within the host. II. Genetic control of acute susceptibility of mice to L. donovani infection. Clin Exp Immunol 30: 130-140.

Cabello PH, Lima AMVM, Azevedo ES, Krieger H 1995. Familial aggregation of Leishmania chagasi infection in northeastern Brazil. Am J Trop Med Hyg 52: 364-365.

Carvalho EM, Bacellar O, Barral A, Badaró R, Johnson WD 1989. Antigen-specific immunosuppression in visceral leishmaniasis is cell mediated. J Clin Invest 83: 860-864.

Carvalho EM, Bacellar O, Brownell CE, Coffman RL, Reed SG 1994. Restoration of IFN-gamma production and lymphocyte proliferation in visceral leishmaniasis. J Immunol 152: 5949-5956.

Carvalho EM, Barral A, Pedral-Sampaio D, Barral-Netto M, Badaró R, Rocha H, Johnson WD 1992. Immunologic markers of clinical evolution in children recently infected with Leishmania donovani chagasi. J Infect Dis 165: 535-540.

Carvalho EM, Horwitz DA 1980. Characterization of a non-T, non-B human blood lymphocyte that mediates the enhancing effects of immune complexes on lymphocyte blastogenesis. J Immunol 124: 16561661.

Cerf BJ, Jones TC, Badaró R, Sampaio D, Carvalho EM, Rocha H, Teixeira R, Johnson WD 1987. Malnutrition as a risk factor for severe visceral leishmaniasis. J Infect Dis 156: 1030-1032.

Corredor A, Gallego JF, Tesh RB, Morales A, Carrasguilla CF, Young DG, Kreutzen RD, Boshell J, Palan MT, Carceres E, Palaez D 1989. Epidemiology of visceral leishmaniasis in Colombia. Am J Trop Med Hyg 40: 480-486.

Costa JML, Osaho NK, Vale KC, Lago EL, França F, Vaxenat JA, Marsden PD 1986. Ocorrência familiar da leishmaniose tegumentar americana em uma região endêmica, Corte de Pedra, Bahia. Rev Soc Bras Med Trop 19: 197-198.

Cunha S, Freire M, Eulálio C, Cristovão J, Netto E, Johnson WD, Reed SF, Badaró R 1995. Visceral leishmaniasis in a new ecological niche near a major metropolitan area of Brazil. Trans $R$ Soc Trop Med Hyg 89: 155-158.

Deane LM, Deane MP 1962. Visceral leishmaniasis in Brazil: Geographic distribution and transmission. Rev Inst Med Trop São Paulo 4: 198-212.

Dhiman RC, Sen AB 1991. Epidemiology of kala-azar in rural Bihar (India) using village as a component unit of study. Indian J Med Res 93: 155-160.

Evans T, Reis M de F, de Alencar JE, Naidu TG, de Jesus JA, Mc Auliffe JF, Pearson RD. 1985. American visceral leishmaniasis (kala-azar). West J Med 
142: 777-781.

Evans TG, Teixeira MJ, McAuliffe IT, Vasconcelos IAB, Vasconcelos AW, Sousa AQ, Lima JWO, Pearson RD 1992. Epidemiology of visceral leishmaniasis in northeast Brazil. J Infect Dis 166: 1124-1132.

Ghalib HW, Piuvezan MR, Skeiky YAW, Siddig M, Hashmi FA, El-Hassam AM, Russo DM, Reed SG 1993. Interleukin-10 production correlates with pathology in human L. donovani infections. J Clin Invest 92: 324-329.

Guedes GE, Maroja A, Chaves E, Estélio J, Cunha MJ, Arcoverde S 1974. Calazar no litoral do estado da Paraíba, Brasil. Encontro de 70 casos humanos e 16 caninos. Rev Inst Med Trop São Paulo 16: 265 269.

Jahn A, Lelmett JM, Diesfeld HJ 1986. Seroepidemiological study of kala-azar in Beringo District, Kenya. J Trop Med Hyg 89: 91-94.

Karp CL, El-Safi SH, Wynn TA, Satt MMH, Kardogani AM, Hashmi FA, Hag-Ali M, Neva FA, Nutman TB, Sacks DL 1993. In vivo cytokine profiles in patients with kala-azar. J Clin Invest 91: 1644-1648.

Lainson R 1983. The American leishmaniasis: some observations on their ecology and epidemiology. Trans $R$ Soc Trop Med Hyg 77: 569-596.

Lowry DH, Rosembrongh NG, Farr AL, Randall RG 1951. Protein measurement with the folin phenol reagent. J Biol Chem 193: 265-275.

Navin TR, Sierra M, Custodio R, Steurer F, Porter CH, Ruebush TK 1985. Epidemiologic study of visceral leishmaniasis in Honduras, 1975-1983. Am J Trop Med Hyg 34: 1069-1075.

Perea WA, Ancelle T, Moren A, Nagelkerke, Sondorp E 1991. Visceral leishmaniasis in southern Sudan.
Trans $R$ Soc Trop Med Hyg 85: 48-53.

Reed SG, Badaró R, Masur H, Carvalho EM, Lorenço R, Lisboa A, Teixeira R, Johnson WD, Jones TC 1986. Selection of a skin test antigen for american visceral leishmaniasis. Am J Trop Med Hyg 35: 7985.

Russo DM, Jardim A, Carvalho EM, Sleath PR, Armitage RJ, Olafson RW, Reed SG 1993. Mapping human T cell epitopes in leishmania gp63. Identification of cross-reactive and species-specific epitopes. $J$ Immunol 150: 932-939.

Southgate BA, Oriedo BVE 1962. Studies in the epidemiology of East African leishmaniasis. I. The circumstancial epidemiology of Kala-azar in the Kitui District of Kenya. Trans R Soc Trop Med Hyg 56: 30-47.

Thakur CP 1984. Epidemiological, clinical and therapeutic features of Bihar kala-azar (including post kala-azar dermal leishmaniasis). Trans $R$ Soc Trop Med Hyg 78: 391-398.

Ward RD 1985. Vector biology and control leishmaniasis, p.199-212. In KP Chang, RS Bray (eds) Leishmaniasis. Elsevier, New York.

Wijers DJB, Killu G 1984. Studies on the vector of kalaazar in Kenya. VIII. The outbreak in Machakos District; epidemiological features and possible way of control. An Trop Med Parasitol 78: 597-604.

WHO - World Health Organization 1990. Control of leishmaniasis. WHO Tech Rep Ser 793: 54

Zijlstra EE, Ali MS, El-Hassan AM, El-Toum IA, Satti M, Ghalib HW, Sondorp E, Winkler A 1991. Kalaazar in displaced people from southern Sudan: epidemiological, clinical and therapeutic findings. Trans $R$ Soc Trop Med Hyg 85: 365-369. 